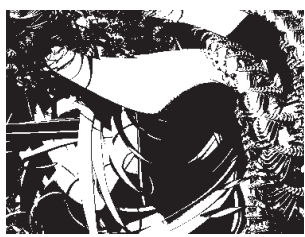

doi:10.5559/di.20.2.06

\title{
HRVATSKA KAO ZAPADNI BALKAN - GEOGRAFSKA STVARNOST ILI NAMETNUTI IDENTITET?
}

Mirela SLUKAN ALTIĆ

Institut društvenih znanosti Ivo Pilar, Zagreb

UDK: $911.3: 32(497.5)$

Pregledni rad

Primlieno: 22. 9. 2009.

Članak raspravlja o pojavi i povijesnom razvoju geografskoga pojma Balkanskoga polvotoka i njegovu utjecaju na suvremeno definiranje geografskoga i geopolitičkoga položaja Republike Hrvatske. Različita, često pogrešna, stajališta u definiranju granica Balkanskoga poluotoka uzrok su mnogim nedoumicama i u regionalizaciji i u određivanju položaja Hrvatske u međunarodnim odnosima. Pojam zapadnoga Balkana, koji se danas često rabi za definiranje geografskoga i geopolitičkoga položaja Hrvatske, u potpunoj je suprotnosti s načelima geografske regionalizacije Europe kao is geografskom definicijom poluotoka.

Ključne riječi: zapadni Balkan, regionalizacija Europe, geopolitika, geografski položaj Hrvatske, identitet

$\triangle \quad$ Mirela Slukan Altić, Institut društvenih znanosti Ivo Pilar, Marulićev trg 19/1, p. p. 277, 10001 Zagreb, Hrvatska. E-mail: Mirela.Altic@pilar.hr

\section{POČETNI PROBLEMI - BALKAN, TO SU ONI DRUGI}

Kada biste danas pitali nekoga u Sloveniji gdje je Balkan, vjerojatno bi uslijedio odgovor da je to svakako negdje istočno od Sutle. Postavivši isto pitanje u Hrvatskoj, uobičajeni odgovor jest da Balkan počinje od Dunava, dok bi u Bosni odgovor glasio da je Balkan istočno od Drine. ${ }^{1}$ Dakle, ne samo da postoji očito nesuglasje o geografskom pojmu Balkana nego i jasna želja da se na njemu ne bude. Balkan, to su uvijek oni drugi. ${ }^{2}$ Iz toga možemo zaključiti da je riječ o pojmu koji ima dva posve različita značenja - geografsko, krajnje nedefinirano, i kulturo- 
DRUŠ. ISTRAŽ. ZAGREB GOD. 20 (2011)

BR. 2 (112),

STR. $401-413$

SLUKAN ALTIĆ, M. HRVATSKA KAO.. loško, krajnje negativno, u novije vrijeme snažno poticano i suvremenim političkim kontekstom koji ponovno revalorizira pojam Balkana u međunarodnim odnosima. Naime, danas se Hrvatska u međunarodnim odnosima u regionalnom smislu često definira kao zemlja zapadnoga Balkana. Iako se te definicije pozivaju na geografsku regionalizaciju prostora, posve je jasno da Hrvatska nema poluotočni položaj, pa prema tome ne može biti ni dio Balkanskoga poluotoka. Pojam Balkana u prostornom opsegu u kojem se obično upotrebljava jest povijesni, a ne geografski pojam. U skladu s tim može se upotrebljavati samo u povijesnom kontekstu, a nikako u kontekstu suvremenih geografskih, geopolitičkih ili međunarodnih odnosa, kao što se to danas često događa.

Iako je geografski pojam Balkana stariji od onoga kulturološkog, geografskih radova koji bi definirali Balkanski poluotok gotovo da nema. Zbog svega navedenog cilj je ovog rada istražiti historijsko-geografsku genezu pojma Balkana i njegov utjecaj za suvremenu regionalizaciju srednje i jugoistočne Europe, koje je Hrvatska sastavni dio.

\section{GEOGRAFSKA DEFINICIJA BALKANSKOGA POLUOTOKA - BALKAN KAO PROBLEM, A NE REGIJA}

Već letimičan uvid u relevantnu geografsku literaturu ističe nejasnu definiciju Balkanskoga poluotoka. Svaka enciklopedija, atlas ili druga stručna literatura s područja geografije navodi drugačije geografske odrednice Balkana.

Balkanski poluotok najčešće se definira kao jugoistočni dio europskoga kontinenta, kojemu je kopnena granica obično određena linijom Trst - Odesa. ${ }^{3} \mathrm{U}$ skladu s tom tezom gotovo je cijeli hrvatski prostor obuhvaćen pojmom Balkanskoga poluotoka. Slično ga definira i Encyclopedia Britannica (1993., vol. 1, 833-835), koja u taj pojam uključuje Grčku, Albaniju, Bugarsku, Rumunjsku te sve zemlje bivše Jugoslavije, uključujući i Sloveniju. Na sličan način isti prostor tretira i The Palgrave Concise Historical Atlas of the Balkans (Hupchick i Cox, 2001., 5), koji sjevernu granicu Balkana stavlja na Dravu, Dunav, Karpate i ušće rijeke Prut u Crno more.

Wikipedija, internetska enciklopedija, označuje Balkan kao poluotok jugoistočne Europe kojemu je poluotočnost neodređena, a koji obuhvaća europski dio Turske, Grčku, Albaniju, Makedoniju, Srbiju i Crnu Goru, Bugarsku, Bosnu i Hercegovinu, a samo katkada i Rumunjsku, Hrvatsku te Sloveniju. ${ }^{4}$

Ističući problematičnost pojma Balkana, World Geographical Encyclopedia (Geografska enciklopedija svijeta) (New York, 1994., 231), sporno područje definira kao Podunavsko-balkansku regiju (Danube-Balkan Region), koja obuhvaća područje Grčke, Albanije, Makedonije, Srbije i Crne Gore, Bosne i Hercegovine, Hrvatske, Madžarske, Rumunjske i Bugarske. 
DRUŠ. ISTRAŽ. ZAGREB GOD. 20 (2011), BR. 2 (112)

STR. $401-413$

SLUKAN ALTIĆ, M. HRVATSKA KAO...
U Atlasu Europe Radovan Pavić (1997., 201) sjevernu granicu Balkanskoga poluotoka definira linijom Riječki zaljev - bugarsko-rumunjska granica na Crnom moru, čime se granica Balkana na hrvatskom prostoru pomiče na Kupu i Savu. Zanimljivo je da istodobno ovaj atlas, prikazujući poluotoke Europe, granice spornoga poluotoka povlači znatno južnije, smještajući na Balkan samo Grčku, Albaniju i Makedoniju (usp. kartu objavljenu na str. 5 istog atlasa).

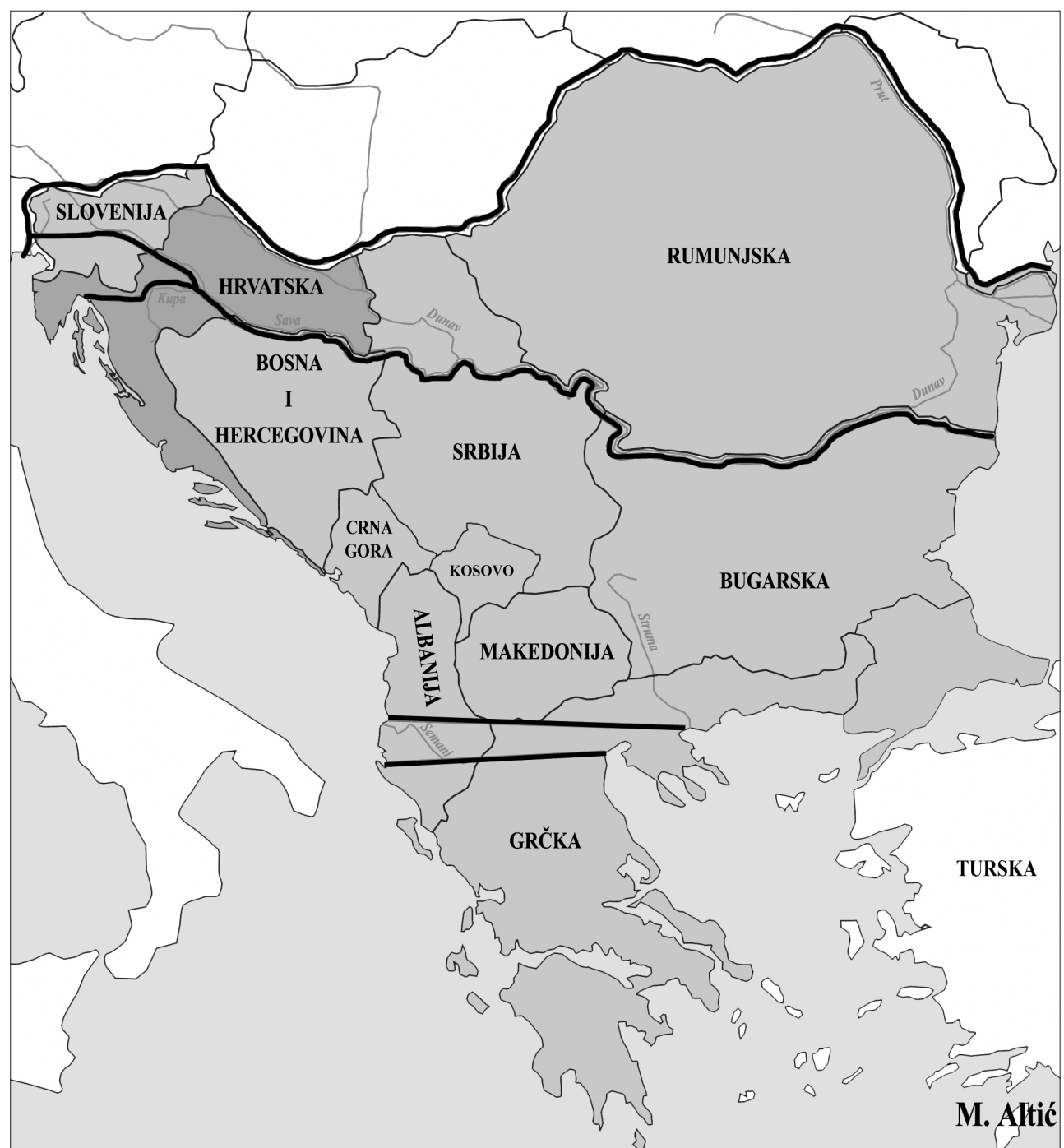

(1) SLIKA 1

Različite geografske definicije Balkana s naznačenim sjevernim granicama njegova prostornog opsega
Uočivši geografsku nelogičnost definicije Balkanskoga poluotoka, već na početku 19. stoljeća, javlja se nova teorija o sjevernoj granici Balkana, koja je na zapadu određena ušćem rijeke Semanija, a na istoku ušćem rijeke Strume (Strymon) u Egejsko more. Tu je granicu zagovarao i jedan od naših naj- 
(1) SLIKA 2

Trokut Trst - Odesa -

rt Tainaron kojim se

najčešće definira

Balkanski polvotok, a

koij ga čini geografski

neodrživim poznatijih geografa, Josip Roglić. Osim ove, javlja se još jedna teza koja određuje Balkanski poluotok kao područje što zatvara linija između Vlore na zapadu i Solunskoga zaljeva na istoku.

Polazeći od geografske definicije poluotoka u kojoj se navodi da je riječ o istaknutom dijelu kopna koji je sa tri strane okružen morem, s tim da najkraća stranica toga zamišljenog trokuta mora biti okrenuta prema kopnu, 5 jasno je da je Balkanski poluotok definiran granicom na Savi i Dunavu geografski neodrživ.

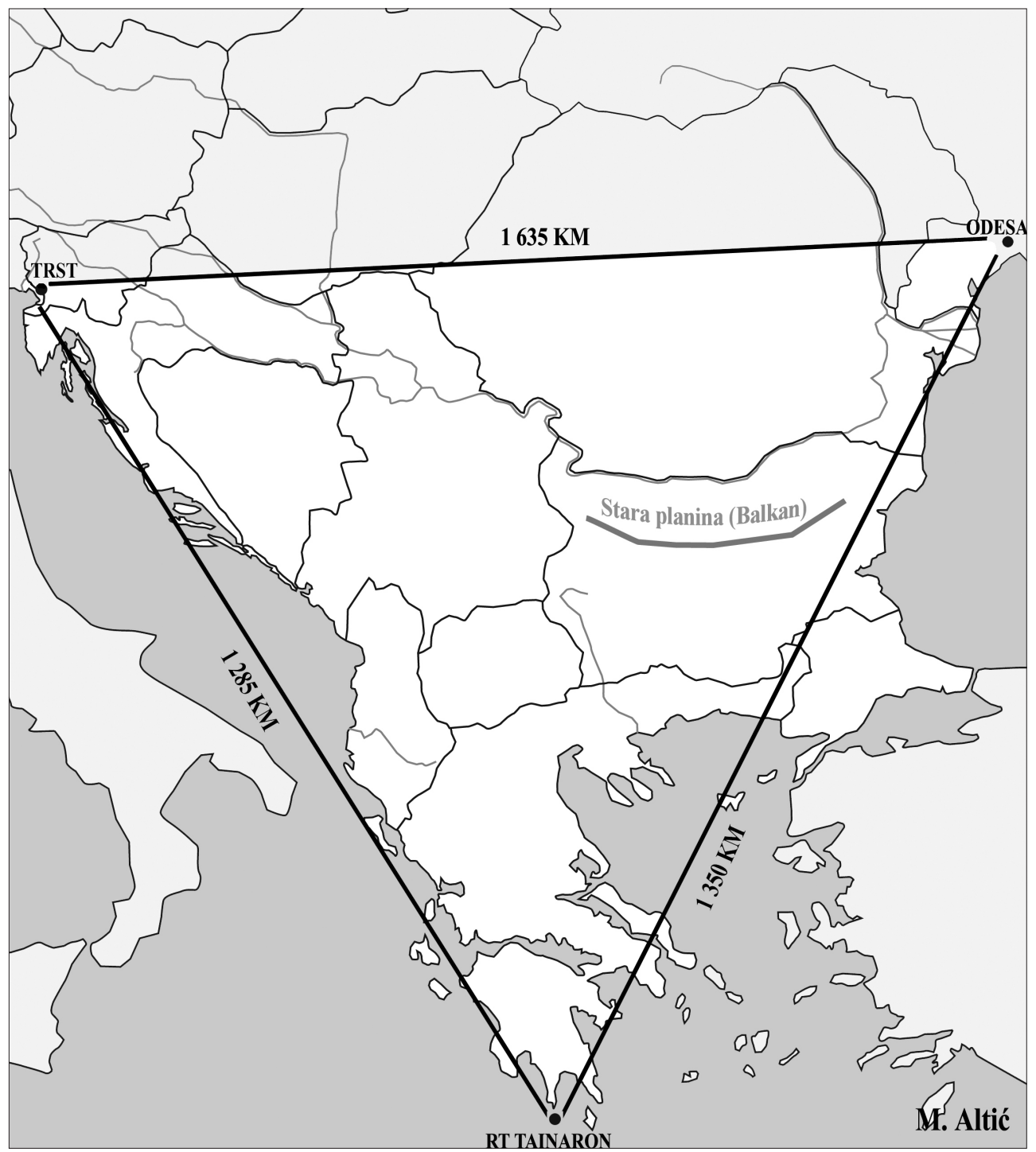

Kopnena stranica toga zamišljenog trokuta određena krajnjim točkama Trstom i Odesom bila bi duga 1365 kilometara, dok bi njezine bočne stranice iznosile 1285 km (Trst - jug Pelo- 
DRUŠ. ISTRAŽ. ZAGREB GOD. $20(2011)$, BR. 2 (112),

STR. $401-413$

SLUKAN ALTIĆ, M. HRVATSKA KAO... poneza), odnosno $1350 \mathrm{~km}$ (Odesa - jug Peloponeza). Dakle, u ovom je slučaju kopnena stranica zamišljenoga trokuta poluotoka najduža, a ne najkraća stranica, trokuta, pa prostor između Trsta, Odese i Tainarona (južni rt Peloponeza) ne može činiti poluotok. Shodno tomu, ni Hrvatska nema poluotočni položaj, pa tako ne može biti ni dio Balkanskoga poluotoka. Od svih tzv. balkanskih zemalja samo Grčka te dijelom Albanija i Makedonija imaju izrazit poluotočni položaj, odnosno kao Balkanski poluotok može se definirati samo prostor južno od planine Balkana, pa onda i naš poznati povijesni geograf Veljko Rogić (1990., 12) za spomenuti poluotok predlaže naziv Grčko-albanski poluotok.

Dakle, pojam Balkanskoga poluotoka koji se danas rabi nema nikakva geografskog utemeljenja, nego je riječ o geopolitičkoj odrednici koja označuje multietnički i politički trusan prostor jugoistočnoga ruba Europe. Kao što je francuski geograf André Blanc ispravno primijetio, pojam Balkana označuje problem, a ne regiju. Da je riječ o političkom, a ne o geografskom, pojmu, najbolje potvrđuje činjenica da Grčku, koja od svih tzv. "balkanskih zemalja" ima najistaknutiji poluotočni položaj, nitko u međunarodnim odnosima danas ne definira kao balkansku zemlju.

\section{BALKAN - MISTERIOZNI POTKONTINENT EUROPE}

Balkanski poluotok dobio je ime po planini u Bugarskoj koja se zove Stara planina. Naziv ove planine ima svoj korijen u grčkoj riječi Aimos, odnosno latinskoj Haemus, što znači planina (Klaić, 1982., 141). U skladu s tim, na svim starim geografskim kartama taj je planinski niz označen njegovim latinskim, odnosno grčkim, imenom. Naziv Balkan turskoga je podrijetla i također označuje planinu. Na zemljopisnim kartama riječ Balkan kao oznaku Stare planine u Bugarskoj nalazimo tek u 17. stoljeću, ${ }^{6}$ no s obzirom na činjenicu da u tom prostoru i prije prodora Osmanlija žive neka turska plemena, naziv Balkan kao oznaka spomenute planine vjerojatno je usvojena znatno prije 17. stoljeća. U književnost Balkan ulazi 1608. godine, kada je njemački svećenik Salomon Schweigger (1551. - 1622.) u diplomatskoj službi Rudolfa II. putujući sultanu Muratu II. u Carigrad, napisao djelo "Die neuen Schriften über die Reise von Deutschland bis Konstantinopel und Jerusalem", koje sadrži najstariji poznati spomen Balkana. U svom djelu Schweigger (1608.) za planinu Haemus kaže "Turci ga zovu Balkan, a puk istočno od njega naziva ga hrvatskim imenom Comonica". No bez obzira na to kada se ime Balkan prvi put javlja, ono se rabilo isključivo kao oznaka spomenutoga planinskog niza. Kako je, dakle, uopće došlo do toga da se ime jedne planine u Bugarskoj proširi na površinu od gotovo 500000 km²? 
DRUŠ. ISTRAŽ. ZAGREB GOD. 20 (2011), BR. 2 (112)

STR. $401-413$

SLUKAN ALTIĆ, $M$. HRVATSKA KAO..
Osoba zaslužna za proširenje pojma Balkana na širi prostor jugoistočne Europe bio je njemački prirodoslovac Johann August Zeune (1778. - 1853.). On je u svom djelu "Gea", napisanom 1809. godine, prvi upotrijebio izraz Balkanski poluotok. Naime, pišući o reljefu toga dijela Europe, Zeune je pogrešno zaključio da se Stara planina pruža od Jadranskoga do Crnoga mora te da ima funkciju središnjega planinskog niza koji europsko kopno dijeli od njegova potkontinenta (Rogić, 1972., 284). Kako je kod imenovanja poluotoka običaj da on najčešće dobije ime po planinskom nizu koji ga dijeli od kopna (npr. Apeninski poluotok, Pirinejski poluotok), tako je i Zeuneov misteriozni potkontinent dobio ime Balkan Halbeiland, koje je kasnije preoblikovao u Balkan Halbinsel. Tako je ime Balkana prošireno na područje čitave jugoistočne Europe pogreškom jednoga prirodoslovca.

\section{BALKAN KAO SUPSTITUCIJA ZA EUROPSKU TURSKU7}

Pojam Balkanskoga poluotoka nije odmah ušao u širu upotrebu. Nakon Zeuneova djela "Gea", koje uvodi sporni pojam, ime Balkanskoga poluotoka u prvoj polovici 19. stoljeća susrećemo razmjerno rijetko. Naime, pojam Balkanskoga poluotoka već tada nisu prihvatili ni znanstvenici ni šira javnost. Njemački geograf Carl Ritter (1779. - 1859.), odmah nakon izlaska Zeuneova djela, izražava svoje neslaganje te ističe da poluotočni položaj ima samo područje južno od Stare planine, pa shodno tomu predlaže da spomenuti poluotok ponese ime Grčki poluotok. S definicijom Balkanskoga poluotoka nisu se slagali ni drugi ugledni geografi onoga doba, kao što su Hermann Wagner (1840. - 1929.), Theobald Fischer, M. I. Newbigen i Karl Albrecht Penck (1933., 11). Godine 1864. austrijski konzul u Turskoj, Johann Georg von Hahn, za isto područje uvodi kompromisni naziv Jugoistočnoeuropski poluotok (Südostereuropäische Halbinsel).

Drugi razlog zbog kojega ranije nije došlo do općega prihvaćanja pojma Balkanskoga poluotoka jest postojanje jedne geografske odrednice koja je imala vrlo sličan prostorni opseg. Bio je to pojam europske Turske, koja je podrazumijevala sve europske zemlje pod osmanskom vlašću. Dakako, granice europske Turske i Zeuneova Balkanskoga poluotoka nisu se sasvim poklapale, no taj je pojam u 19. stoljeću najčešće rabljen kao regionalna odrednica europskoga prostora južno od Save i Dunava. ${ }^{8}$ U vrijeme ratova s Osmanlijama pripadnost kršćanskom ili islamskom svijetu bila je temeljna regionalna odrednica, pa je tako i ovaj, iako povijesno uvjetovan, pojam našao svoje mjesto $u$ tadašnjoj geografskoj regionalizaciji Europe. Kada se Berlinskim kongresom počela dramatično mijenjati geopolitička slika Europe, pojam europske Turske izgu- 
DRUŠ. ISTRAŽ. ZAGREB GOD. 20 (2011), BR. 2 (112)

STR. $401-413$

SLUKAN ALTIĆ, $M$. HRVATSKA KAO... bio je svoju funkciju (Kalmeta, 1993., 257). Valjalo je naći novu geografsku odrednicu koja bi pokrivala taj isti dio Europe. Tada je, usprkos protivljenju znanstvenika, ponovno revitalizirano ime Balkanskoga poluotoka. Kako je tada pojam Balkana uveden kao supstitucija pojma europske Turske, tako se njegove sjeverne granice više nisu poistovjećivale sa Zeuneovim središnjim planinskim lancem, nego s dosezima turskih osvajanja u 19. stoljeću. Dakle, došlo je do korigiranja prostornog opsega Balkana, koji je sada češće obuhvaćao samo područje južno od Save.

Da je geografski pojam Balkana potkraj 19. i na početku 20. stoljeća zaista primarno povezan s osmanskim teritorijem u Europi, potvrđuju i zemljopisne karte iz toga razdoblja. Naime, dok karte Balkanskoga poluotoka nastale do 1878. redovito uključuju Bosnu, one nastale kasnije, dosežu na sjever samo do Srbije i Crne Gore, odnosno onoliko koliko je bilo potrebno da se prikaže tadašnji osmanski teritorij u Europi, odnosno poprište balkanskih ratova, isključujući tako i Grčku, koja također više nije bila pod osmanskom okupacijom..$^{9}$ Jedine karte koje i u 20. stoljeću u sklopu Balkanskoga poluotoka prikazuju Hrvatsku i Bosnu jesu jugoslavenske provenijencije, na kojima se primjećuje učvršćivanje imena Balkana, upravo u doba konačnoga potiskivanja Osmanlija i formiranja nacionalnih država na prostoru jugoistočne Europe..$^{10}$ Dakle, pojam Balkanskoga poluotoka, kao i pojam europske Turske, oba povijesno uvjetovana granicama Osmanskoga Carstva, izdignuti su na status geografske regije pod utjecajem jugoslavenskih izdanja 20. stoljeća, kada Osmansko Carstvo više ne postoji.

\section{ULOGA JOVANA CVIJIĆA}

U revitalizaciji imena Balkan osobitu je ulogu imao srpski geograf Jovan Cvijić (1865. - 1927.), koji u Parizu objavljuje svoje djelo "Balkanski poluotok - humana geografija". Simptomatično, Cvijićevo djelo objavljeno je upravo u Parizu 1918. godine, gdje se odlučivalo o stvaranju Kraljevine SHS.11 Tada je valjalo naći elemente uvjetno homogene geografske regionalizacije koji bi naglasili "logično jedinstvo" prostora novoformirane države na kojem žive evidentno različiti narodi različita povijesnog i kulturnog identiteta. Upravo je Cvijić za potrebe vremena pomaknuo granicu Balkana na Soču i alpski planinski sustav u zaleđu, obuhvativši tako tim poluotokom i čitavu Sloveniju, ustvrdivši da je riječ o prostoru dokle doseže migracija Srba (Cvijić, 1922., 1-5). Sjeverne granice Balkana i prije su uzimane kao "prirodne" granice područja na kojem žive "Srbohrvati",12 no Cvijić je jedini iz spomenute teze razvio či- 
DRUŠ. ISTRAŽ. ZAGREB GOD. 20 (2011)

BR. 2 (112),

STR. 401-413

SLUKAN ALTIĆ, M. HRVATSKA KAO.. na etnobiološkom izjednačavanju i stapanju Srba na Balkanu, granice kojega se spretno poklapaju upravo s granicama Kraljevine. Tako je pojam Balkanskoga poluotoka dobio i svoju državnopravnu potvrdu u stvaranju Kraljevine.

Iako njegova definicija sjeverozapadnih granica Balkana, koja je uključivala Hrvatsku i Sloveniju, nije bila opće prihvaćena, ideja o Balkanskom poluotoku dobro je poslužila kao argument utvrđivanja novih granica na temelju tzv. etničkoga principa. Balkan predstavljen kao etnički homogen prostor bio je nužan u naglašavanju jedinstva očito heterogenoga prostora.

\section{UTJECAJ POJMA BALKANA NA SUVREMENO DEFINIRANJE REGIJE JUGOISTOČNE EUROPE}

Položaj Hrvatske na dodiru povijesnoga pojma srednje Europe i Balkana nije samo trajno obilježio njezin povijesno-geopolitički razvoj. Povijesni pojam Balkana prenijet je i u suvremenost, postajući važan čimbenik suvremenih regionalizacija ovoga dijela Europe.

Pojam Balkana sredinom 20. stoljeća rijetko se rabio. Zbog izrazito negativnih kulturoloških konotacija Balkana, bilo je nužno pronaći nov naziv za istu regiju. Rješenje je pronađeno u pojmu jugoistočne Europe, koja označuje široko područje između Jadranskoga i Crnoga mora. Tako je jugoistočna Europa postala jedna od inačica kojim se označuje nekadašnji pojam Balkana.

Geografski pojam jugoistočne Europe nastao je u najboljoj namjeri da se izbjegne negativno naslijeđe vezano uz ime Balkana. No naizgled dobro rješenje i ovdje je samo prividno. Granice jugoistočne Europe ponovno nisu određene geografskim čimbenicima nego povijesnim granicama Balkana. Geografski gledano, prostor koji je definiran kao jugoistočna Europa ne čini jugoistok europskoga kontinenta nego središnji dio južnoga europskog pročelja koje se proteže od Pirinejskoga poluotoka do Povoložja. Riječ je, dakle, o središnjem dijelu južne Europe. Geografska regija jugoistočne Europe opravdana je samo uz uvjet ako se Rusija ne smatra dijelom Europe. Jedino bi u tom slučaju taj dio europskoga kontinenta zaista činio njegov jugoistočni dio. Iz toga problema proizlazi i sve češće definiranje Hrvatske kao zemlje srednje Europe, koja osim tradicionalnih srednjoeuropskih zemalja obuhvaća i središnji dio južnoeuropskoga pročelja u kojem se nalazi i Hrvatska.

Padom komunizma potkraj 1980-ih Balkan kao geografska odrednica ponovno se češće upotrebljava. Ta se pojava vezuje uz početak formiranja novih država te ratne sukobe 
DRUŠ. ISTRAŽ. ZAGREB GOD. 20 (2011), BR. 2 (112)

STR. $401-413$

SLUKAN ALTIĆ, $M$ HRVATSKA KAO... skoj, nego o političkoj regionalizaciji prostora. Tako Encyclopedia Britannica za narode i države Balkana navodi sljedeća obilježja: "fluidnost etničkih skupina, nesposobnost naroda u regiji da se uzajamno slože i surađuju, sklonost k zloporabi vlasti na lokalnoj razini čim oslabi središnja vlast, utjecaj stranih sila, teškoće s prihvaćanjem koncepcija koje su se razvile u drugom političkom i društvenom kontekstu." Iz pojma Balkana izveden je i pojam balkanizacija, koja po Academic American Encyclopedia (1988.) označuje "raspad nekog područja na male i međusobno neprijateljske jedinice" (Klemenčić, 1999., 18). Dakle, jedna geografska regija definirana je političkim kriterijem, kojem ne bi smjelo biti mjesta u geografskoj regionalizaciji prostora.

\section{ZAPADNI BALKAN KAO POLITIČKI KONCEPT}

U U suvremenim međunarodnim odnosima i u nizu dokumenata Europske unije Hrvatska je zajedno s ostalim zemljama bivše Jugoslavije bez Slovenije, a zajedno s Albanijom, svrstana u regiju zapadnoga Balkana, bez obzira na očitu različitost $\mathrm{u}$ društvenom razvoju te njezinu pripadanju sredozemnom i srednjoeuropskom kulturnom krugu tijekom cijele njezine povijesti. Kao i ranije, takva regionalizacija nije rezultat nekoga društveno-geografskog principa, nego isključivo međunarodnih interesa i okolnosti nastalih u Europskoj uniji nakon 1991. godine. Usprkos čestoj upotrebi u međunarodnim odnosima, pojam zapadni Balkan još se ne može naći ni u jednom politološkom rječniku (Topalović, 2000., 145). Riječ je o posve novom pojmu kojim se pokušava opisati strategija Europske unije prema regiji bivše Jugoslavije, s iznimkom Slovenije i dodatkom Albanije, a koji se onda promiče i kao geografska odrednica istoga prostornog opsega (Milardović, 2000., 37).

Prve političke ideje i inicijative o rekonstrukciji Balkana kao novoj regiji Europe javljaju se već 1993 . godine, ${ }^{13}$ no politički koncept zapadnoga Balkana intenzivnije se razvija tek 1997. godine. Naime, u travnju 1997. godine Opći savjet Europske unije usvojio je Politiku regionalnoga pristupa za zemlje zapadnoga Balkana. Pojam zapadnoga Balkana uveden je i u institucije EU-a kada je u okviru Vijeća ministara EU-a osnovano posebno regionalno povjerenstvo Vijeća ministara za Zapadni Balkan (Council for the Western Balkans), koje tvore diplomati članica zemalja EU-a, neki članovi Europske komisije i članovi tajništva Vijeća ministara. ${ }^{14}$ Čak se u dokumentu Proces stabilizacije i pridruživanja zemalja jugoistočne Europe (Bruxelles, 26. svibnja 1999.), u kontekstu pitanja regionalnoga pristupa, govori o "zajedničkoj strategiji". U političkoj afirmaciji pojma zapadni Balkan osobitu je ulogu imalo skupno izvješće Europske unije pod naslovom "Uloga unije u 
DRUŠ. ISTRAŽ. ZAGREB GOD. 20 (2011), BR. 2 (112)

STR. $401-413$

SLUKAN ALTIĆ, $M$. HRVATSKA KAO.. svijetu", gdje se u sedmom odjeljku pod naslovom "Odnosi sa zemljama zapadnog Balkana" prvi put decidirano i geografski definira zapadni Balkan kao područje Hrvatske, Bosne i Hercegovine, Albanije, Makedonije i SRJ. Od tada zapadni Balkan ne označuje samo virtualni politički pojam nego i jedinstvenu geografsku regiju, svojevrsnu "pod-Europu, dakako definiranu prvenstveno određenom vanjskom politikom Europske unije prema navedenom prostoru" (Milardović, 2000., 40). Iznova je politički koncept odredio granice regije.

\section{UMJESTO ZAKLJUČKA}

Europa je geografska cjelina sastavljena od raznoraznih regija, koje su odraz unutrašnje raznolikosti kontinenta. Geografska regija obuhvaća dio kontinenta zajedničkih ili sličnih osobina koje proizlaze iz jedinstvenih pejsažnih ili funkcionalnih osobina. Ako je Balkan neprihvatljiv pojam zbog njegove povijesne uvjetovanosti i geografske neutemeljenosti, a jugoistočna Europa zbog definiranja Rusije kao europske zemlje geografski netočna, postavlja se logično pitanje: postoji li geografski utemeljen naziv za prostor jugoistočne Europe?

Danas se u suvremenoj regionalizaciji Europe rjeđe primjenjuju kriteriji uvjetno-homogene ili funkcionalne regionalizacije nego sintetički, koji regije ne dijele oštrim crtama nego prijelaznim pojasima. U takvoj sintetičkoj regionalizaciji Hrvatska je najčešće definirana kao prijelazni prostor srednje i južne Europe, odnosno njezin kontinentalni dio pripada srednjoeuropskom području, a obalni južnom, mediteranskom.

No kriteriji geografske regionalizacije podložni su promjenama i/ili potrebama vremena te povijesno-političkom kontekstu. Tako je, nažalost, moguće da u jednom trenutku jedan od kriterija regionalizacije postane i političko subjektivno viđenje neke zemlje, kao i njezino definiranje povijesnim kontekstom koji ne postoji već nekoliko stotina godina. Zbog toga je geografska regionalizacija Europe obilježena mnogim koncepcijama i stalnim promjenama. Zemlje položene na rub regija lako se tako sele iz jedne cjeline u drugu, namećući im identitet koji tvorcu međunarodnih odnosa najbolje odgovara. $U$ skladu s navedenim, na pitanje je li za Hrvatsku zapadni Balkan geografska stvarnost ili nametnuti identitet odgovor je, nažalost, trenutačno potvrdan na obje ponuđene teze.

\section{BILJEŠKE}

${ }^{1}$ Jedine europske zemlje koje se danas same predstavljaju kao zemlja Balkana jesu Makedonija i Bugarska.

2 Više o kulturološkim konotacijama usp. Rihtman Auguštin (1997.).

3 Točnije, linija je određena pravcem ušća rijeke Isonzo (Soča) - Vipava - Krka (u Sloveniji) - Sava - Dunav.

4 Usp. http://hr.wikipedija.org/wiki/Balkan 
DRUŠ. ISTRAŽ. ZAGREB GOD. 20 (2011), BR. 2 (112)

STR. $401-413$

SLUKAN ALTIĆ, M. HRVATSKA KAO...
5 Geografski rječnik, u izdanju Hrvatskog geografskog društva, str. 397, natuknica poluotok (urednik Damir Magaš, 2002.).

6 U tom smislu pogrešni su navodi iz Enciklopedije Islama (Islâm Ansiklopedisi, 1970., str. 280-285), koje preuzima i Sekulić (1999., 83), da se ime Balkan za Staru planinu na kartama javlja tek u drugoj polovici 18. stoljeća. Autor ovih redaka već je letimičnim pregledom karata 17. stoljeća našao veći broj spomena imena Balkan. Jedan od starijih nalazimo na karti "Corso del Danubio", koju je izradio 1684. godine rimski kartograf Giacomo Cantelli da Vignola.

7 Pod pojmom europske Turske razumijevamo europski dio Osmanskoga Carstva. Iako je riječ o izrazito europocentrističkom pojmu koji suvremena historiografija nije prihvatila, taj se izraz $u$ europskoj literaturi u 18. i 19. stoljeću uvelike upotrebljava za označavanje osmanskoga teritorija u Europi, osobito kada je u pitanju geopolitika, te je $u$ tom smislu imao značajan utjecaj na tadašnju regionalizaciju Europe.

8 Tijekom 18. i 19. stoljeća izrađen je velik broj kartografskih prikaza europskoga teritorija pod osmanskom vlašću koje su redovito nosile naziv "karta europske Turske".

9 Usp. Najnovija karta balkanskih država (hrvatsko izdanje Freytagove karte), nastala na početku 20. stoljeća, svakako prije 1913. godine (HDA, Kartografska zbirka, sign. E.XVI.42 ili pak češka Mapa Balkana iz istog razdoblja (HDA, Kartografska zbirka, sign. E.XVI.75).

${ }^{10}$ Karta Balkanskoga poluostrva iz 1913. godine, objavljena u Beogradu u izdanju Gece Kohna, prikazuje Balkanski poluotok u granicama koje je definirao Zeune u 19. stoljeću (HDA, Kartografska zbirka, sign. E.I.166).

11 Kako je 1918. godine knjiga objavljena na francuskom, 1922. godine objavljena je u Beogradu pod malo drukčijim naslovom "Balkansko poluostrvo i južnoslovenske zemlje: osnove antropogeografije".

12 Usp. Istorijsko-etnografsko geografska mapa Srba i srpskih (jugoslovenskih) zemalja u Turskoj i Austriji. Kartu je 1873. godine izradio Miloš Milojević, a izdao Kosta Astadinov Šumenković u Beogradu.

13 Opširnije o tome usp. Milardović, Anđelko (2000.): Zapadni Balkan: pojam, ideje i dokumenti o rekonstrukciji Balkana u procesu globalizacije, str. 19-36.

14 Samo od 1998. do 2000. Regionalna radna skupina Vijeća ministara EU-a za zapadni Balkan producirala je niz dokumenata koji su između ostalog objavljivani u Glasnicima EU-a (10/1998., 5/99., 6/1999., 7/8/1999., 9/1999., 10/1999., 11/1999., 1-2/1999., 3 i 4/2000., 5/2000.).

\section{LITERATURA}

danje Armanda Colina.

Cvijić, J. (1922.), Balkansko poluostvrvo i južnoslovenske zemlje: osnove antropogeografije, Beograd: Državna štamparija Kraljevine S.H.S.

Encyclopedia Britannica (1993.), vol. 1; 833-835. 
DRUŠ. ISTRAŽ. ZAGREB GOD. 20 (2011) BR. 2 (112),

STR. $401-413$

SLUKAN ALTIĆ, $M$ HRVATSKA KAO.
Hupchick, D. i Cox, H. (2001.), The Palgrave Concise Historical Atlas of the Balkans, New York: Palgrave.

Islâm Ansiklopedisi (1970.), Istanbul, str. 280-285.

Kalmeta, R. (1993.), Da li je Republika Hrvatska "balkanska država"? Hrvatska revija, 43 (2/3): 256-264.

Klaić, B. (1982.), Rječnik stranih riječi: tuđice i posuđenice, Zagreb: Nakladni zavod Matice hrvatske.

Klemenčić, M. (1999.), Jugoistočna Europa - definicija pojma i razvitak političkog zemljovida. Međunarodni znanstveni skup "Jugoistočna Europa 1918.-1995.". Hrvatska matica iseljenika i Hrvatski informativni centar, Zagreb, str. 18-21.

Magaš, D. (ur.) (2002.), Geografski rječnik, Zadar: Hrvatsko geografsko društvo, natuknica poluotok, str. 397.

Milardović, A. (2000.), Zapadni Balkan: pojam, ideje i dokumenti o rekonstrukciji Balkana u procesu globalizacije, Osijek, Zagreb, Split: Pan liber.

Pavić, R. (1997.), Balkan. Atlas Europe, Leksikografski zavod "Miroslav Krleža", Zagreb, str. 200-201.

Penck, K. A. (1933.), Nordgrenze der Balkan-Halbinsel. Forschungen und Fortschritte, Berlin, br. 9, str. 11.

Rihtman Auguštin, D. (1997.), Kad i otkad se grozimo Balkana? Erasmus, 19: 27-35.

Rogić, V. (1972.), Balkanski poluotok, natuknica u Pomorskoj enciklopediji, sv. 1, str. 284-285.

Rogić, V. (1990.), Regionalna geografija Jugoslavije, Zagreb: Školska knjiga. Schweigger, S. (1608.), Die neuen Schriften über die Reise von Deutschland bis Konstantinopel und Jerusalem. Nürnberg.

Sekulić, B. (1999.), To Remove the Anathema of the Balkans. Politička misao, XXXVI (5): 78-92.

Topalović, D. (2000.), Balkanska Europa, Zagreb: Diorama.

World Geographical Encyclopedia (1994.), Danube-Balkan Region. New York, str. 231-232.

Zeune, J. A. (1809.), Gea. Versuch einer wissenschaftlicher Erdbeschreibung, Berlin.

\section{Croatia as a Part of the Western Balkans - Geographical Reality or Enforced Identity?}

Mirela SLUKAN ALTIĆ

Institute of Social Sciences Ivo Pilar, Zagreb

The article discusses the appearance and historical development of the geographical term "Balkan Peninsula". Special attention is drawn to the impact of the historical term of Balkan Peninsula on the contemporary definition of the 
DRUŠ. ISTRAŽ. ZAGREB GOD. 20 (2011), BR. 2 (112)

STR. $401-413$

SLUKAN ALTIĆ, $M$. HRVATSKA KAO... geographical and geopolitical position of the Republic of Croatia today. Very different points of view on what the Balkan peninsula is geographically, are currently causing considerable disagreement in the contemporary regionalization of south-eastern Europe as well as problems regarding the regional affiliation of Croatia in international affairs. The term "Western Balkans" frequently used today as the definition of the geographical position of the Republic of Croatia, is in total discrepancy with the criteria of geographic regionalization and with the geographical definition of what a peninsula is.

Keywords: Western Balkans, regionalization of Europe, geopolitics, geographical position of Croatia, national identity

\section{Kroatien als westlicher Balkan - geografische Wirklichkeit oder aufgezwungene Identität?}

Mirela SLUKAN ALTIĆ

Ivo Pilar-Institut für Gesellschaftswissenschaften, Zagreb

Im Artikel werden die Entstehung und geschichtliche Entwicklung des geografischen Begriffs der Balkanhalbinsel sowie seine Auswirkungen auf die moderne Bestimmung der geografischen und geopolitischen Lage der Republik Kroatien erörtert. Unterschiedliche, oft auch falsche Ausgangspositionen bei der Definierung der Grenzen der Balkanhalbinsel sind die Ursache dafür, dass bei der Regionalisierung sowie bei der Lagebeschreibung Kroatiens im internationalen Rahmen vielfach Ratlosigkeit herrscht. Der Begriff des Westbalkans, der heute oft zur Bestimmung der geografischen und geopolitischen Lage Kroatiens gebraucht wird, steht in völligem Gegensatz zu den Prinzipien der geografischen Regionalisierung Europas sowie der geografischen Definierung der Balkanhalbinsel.

Schlüsselbegriffe: Westbalkan, Regionalisierung Europas, Geopolitik, geografische Lage Kroatiens, Identität 